\title{
Study of The Hadith of Female Leadership
}

\author{
$1^{\text {st }}$ A Saeful ${ }^{1}, 2^{\text {nd }}$ A I Imamah ${ }^{2}, 3^{\text {rd }}$ Amrin $^{3}, 4^{\text {th }} \mathrm{M} \mathrm{Huda}^{4}, 5^{\text {th }}$ S A H Almunawar ${ }^{5}$, \\ $6^{\text {th }}$ A Fudhaili ${ }^{6}$ \\ \{ achmad.saefu120@mhs.uinjkt.ac.id ${ }^{1}$, ade.irma20@mhs.uinjkt.ac.id ${ }^{2}$ \\ amrin20@mhs.uinjkt.ac.id ${ }^{3}$, miftahulhuda20@mhs.uinjkt.ac.id ${ }^{4}$, said.agil@uinjkt.ac.id ${ }^{5}$, \\ ahmad.fudhaili@uinjkt.ac.id ${ }^{6}$ \} \\ UIN Syarif Hidayatullah Jakarta ${ }^{1,2,3,4,5,6}$
}

\begin{abstract}
This article discusses the Hadith of Women's Leadership. In this paper, it is explained that the hadith that prohibits women's leadership has a correlation with the destruction of the Persian Empire which was then led by a woman. From this context, the issue of Women's Leadership gives birth to two views, namely those that approve and reject it. Those who agree with the leadership of women, they think that the Hadith is contextual and valid for the time being. Therefore, the Hadith is not universal or the prohibition applies to all women. For those who reject it, they think that the hadith that prohibits women's leadership applies not only to the context of the past but also to all ages. From both opinions it appears that the issue of Women's Leadership to date still breeds debate, one side many agree with Women's Leadership, on the other hand not a few who reject it.
\end{abstract}

Keywords: Leadership, Women, Hadith, Textual, Historical

\section{Introduction}

The theme of female leadership in Islam is actually a classic theme. However, until now the theme is still polemic. Broadly speaking polemics on this issue give rise to two views; views that disapprove of women's leadership and approve of it. Groups that disagree, assume that women do not have the qualifications to be leaders. Because the role of women is actually only in the domestic area, not in the public area.[1]

It is not uncommon for arguments that are built by groups that do not agree to be taken from religious evidence, and the most commonly referred to as QS. Al-Nisa'/4:34 in the word of Allah, and Allah is All-Know. "Al-rijâlu qawwâmûna 'al-nisâ'i, men are protectors of women." A protective sentence for women, indicating that women are a weak group. There is no way a weak group can be made a leader.[2, hal. 5]

For groups that agree, of course the above opinion is unacceptable. Restricting women only to domestic areas, certainly no longer in accordance with the current conditions. It is evident today that not a few women are able to become leaders.[3, hal. 71] In the Indonesian context, this kind of condition often occurs, ranging from the highest leadership of the country (President) to regional leaders (Governors, Regents, and so on).[4, hal. 193]

On the other hand, it relates to QS. an-Nisa'/4: 34, the female protector means the point of weight is in the realm of the family, not in the public domain. Even today, sometimes not a few women also act as protectors of the family, such as making a living to finance family life. 
Therefore, the understanding of the verse does not necessarily have to be understood textually, but it should also be understood contextually. [5, hal. 5-7]

The problem of female leadership does not only occur in Islam. Before Islam came this problem often appeared. In ancient Greek society, for example, women were only considered as male needs- so their existence was not worthy of becoming a leader.[6] After three money with the Greek people, in the 6th century AD held a meeting stating about the disconcertingness of women, whether including humans or not. Although the result of the meeting stated that women are human beings, their position was only placed as a male ministry. In fact, in the Christian teachings of the past, women are considered satanic weapons to mislead people.[7]

In the land of Islamic birth, before her arrival, women often get unpleasant treatment, used as an impediment to lust for men, their status is dwarfed and considered a disgrace, even worse every girl born must be buried alive.[8] Women are also like merchandise that can be found in the markets. Young men who have a lot of inheritance from their parents are entitled to buy women in the market. In order to gain a great profit, women are also equipped with a little skill by the owners, such as singing, embroidery and so on.[9]

Various images of women before the arrival of Islam are so sad, the treatment that has an element of humanity is always denied from women, when Islam comes, the whole practice is forbidden and the position of women is then initiated. Not a few verses of the Qur'an equal the position between men and women.[10]

Aminah Wadud (L. 1952 AD) pays special attention to the general concept of the Qur'an about women. For him, God gave equality between men and women from the beginning of the creation of man, both created from the same element and earned the same rights as the caliphs on earth and both have a chance of success in heaven. This kind of equation shows that women also have similar potential to men and Islam strongly responds positively to the similarities.[11, hal. 44]

However, the cynical presumption against women has not stopped. Proven boundaries to women to date are often raised, with no exception in the issue of leadership. Restricting women from becoming leaders is certainly not a simple matter, it requires a thorough study. One of them is by studying hadith that talks about female leadership.

\section{Methodology}

This study uses a qualitative type with library research methods, by explaining the arguments from the data sources obtained in the form of studies, so that they can examine women's leadership in Islam. The approach used is the descriptive analysis approach. Sources of data in this study using primary data. The primary data is Said Aqil Husin al-Munawwar's book on Asbâbul Wurûd: A Critical Study of the Prophet's Hadith through a Socio-Historical and Contextual Approach. Secondary sources are books, books, historical documents, mass media, journals and other sources related to the problem under study.

The data analysis used is qualitative data analysis that describes and analyzes the study of women's leadership in Islam, so that they can understand the dynamics, legal status, views of the problems studied. 


\section{Result and Discussion}

\subsection{Leadership in Islam}

The term leadership is not a foreign term in Islam. The term is often labeled to someone who has the highest power and great influence, whether in a country, region, organization and the like. If it refers to the Islamic teachings of the concept of leadership can not be released penance to the Prophet Muhammad saw. This belief is true because the Prophet (s) was able to bring his followers to the joy of success, from the initially unaccounted for to be very calculated. In fact, the success of the Prophet's leadership was not only in the territory of religion but also in the territory of the state. [12]

After the Prophet (s) died the leadership continued to the four Caliphs, ranging from Abu Bakr, Umar Bin Khattab, Usman Bin Affan to Ali Bin Abi Thalib. During the leadership of the people, the caliphs had great merit, because under the leadership of the caliphs the teachings of Islam can survive and continue to develop. Although their leadership is not separated from the conflict, the services given to Islam are difficult to deny.[13]

The transition of Islamic leadership from the four caliphs switched to two major dynasties, the Muawiyah Dynasty and the Abbasid Dynasty. After Ali Ibn Abi Talib was killed, the power then turned to Mu'awiyah Bin Abi Sofyan and continued by his descendants. During this Dynasty, Islamic teachings spread throughout the world. The phase during the Mu'awiyah Dynasty was the expansion phase of the territory.[8]

After the Mu'awiyah Dynasty suffered setbacks, the transition of power switched to the Abbasid Dynasty. During this dynasty, science was very advanced, especially during the reign of Harun al-Rashid and his son named al-Ma'mun. Where during the leadership managed to establish Bait al-Hikmah, a large library that serves as a place to translate the works of scientists outside Islam, especially scientists from Greece. From this, there appeared many great scientists in Islam who were influential to the world, such as al-Farabi, Ibn Sina and other scientists. For centuries the progress of Islam continued to develop, until finally Islam suffered a setback. This setback was also the cause of the loss of the concept of leadership in Islam in the form of $a$ Caliph. This happened precisely when Kemal el-Taturk took over the Turkish leadership.[1]

When looking at the history of the journey of leadership in Islam, starting from the time of the Prophet saw., the companions and Dynasties of Islam. Those who become leaders are people who are powerful and have great influence over their society. So it is not wrong when it is said that the leader is someone who has great influence and holds power over a region. Because of the greatness of influence he has, a leader is very easy to give orders to whomever he wants. In the meantime, someone given an order by a leader will find it difficult to refuse the request.[15]

If you look at the history of leadership in Islam in the past, almost all of the leaders are men, except Aisha Bin Abu Bakr, who is also the leader of the war not as the leader of the country. The domination of male leadership in Islam in the past, eventually gave birth to a strong doctrine/understanding in some Muslims that the territory of leadership is the territory of men not the territory of women.[16] Whereas when looking at the concept of leadership there is no formula that makes the condition of the leader is male. Because in that concept, a leader is one who has great power and influence for the people who are led. In other words, anyone who has these things, both male and female, can then be said to be a leader. Because the issue of female leadership is still problematic, it is necessary to examine the Hadith related to female leadership, so that the perspective related to this issue can be clearly illustrated, whether it is permissible or prohibited. 


\subsection{Women Leadership in Hadith}

such as Saheeh Bukhari (it is twice in Hadith no. 4425 and 7099), Sunan Turmudzi (the one time in Hadith no. 2341, Sunan an-Nasai (it is once in Hadith number 5405), Musnad Ahmad (the six times in Hadith number, 20940, 20977, 210114, 21018 and 21058. But what will be shown is the Hadith of Saheeh Bukhari and an-Nasa'i. In addition to having almost the same meaning, hadith derived from Saheeh Bukhari and an-Nasa'i is enough to represent other hadiths. The editors of the two Hadith are:

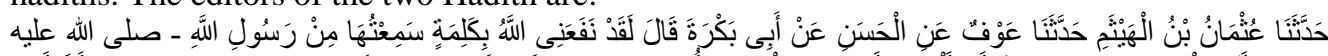

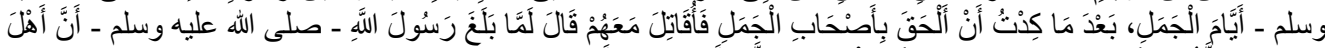

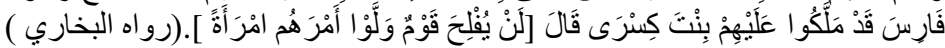

"Had told us Uthman ibn Hisham, had told us Auf of al Hasan of Abu Bakrah he said; " Allah has benefited me because of a word I have heard from the Messenger of Allah. In the days (of war) Jamal after I almost joined those who participated in the war Jamal, and fought with them." He said; "When the news came to the Prophet (s) that the Persians had appointed Kisra's daughter as their leader, he said, "I will not be among the losers." no one will be successful in entrusting their affairs to a woman." (HR. Bukhari)

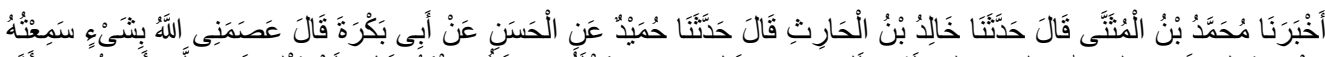

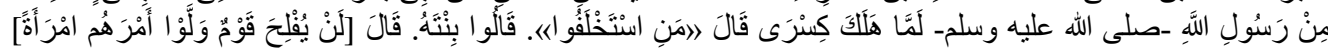

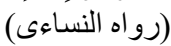

"From Muhammad ibn Mutsanna of Khalid ibn Harits of Humaid of Hasan of Abi Bakrah said: Allah guarded me with something I heard from the Messenger of Allah when the destruction of Kisra, he said: Who replaced him? They said, "My daughter. The Prophet (peace and blessings of Allah be upon him) said: "No people will be successful in giving up their affairs to a woman." (HR. and-Nasa'i)

Of the two Hadiths above the sentence that became the basis for not making women as leaders is in the sentence; lan yuflih qaumun even though amrahum imraatan; will not be lucky a people who give up their affairs to a woman". The sentences in the two Hadiths are often used as justification for groups that refuse about women's leadership. In fact, not a few scholars make the hadiths above as a form of the legal footing to prohibit/reject the leadership of women.[17]

For Imam Malik (D. 795 AD), Imam Shafi'I (D. 820 AD), and Imam Ahmad bin Hanbal (D. 855 AD), as al-Qardhawi said (L. 1926 AD), that the two Hadiths above become the basis if women do not have the eligibility to be leaders so that the right to be leaders is male. This opinion was affirmed by al-Baghawi (D. 516 H/1122 AD), if women were not legitimate leaders. On the other hand, al-Baghawi (D. 516 H/1122 AD) asserts that the inability of women to be leaders is because a leader must go out and fight/fight for the interests of the nation and must be able to handle all the affairs of his community well. It is impossible for this kind of thing to be done by a woman, while the position her is a weak creature.[18, hal. 322][3]

Not infrequently these Hadiths are reinforced by the condition of female nature, that the inability of women to be leaders, in addition to being weak other elements must be present in women, such as menstruation that comes every month, pregnancy and childbirth and breastfeeding and caring / educating their children. This kind of natural condition makes women psychically and emotionally easily disturbed. Thus making his condition often unstable. Therefore, it is highly unlikely that women can expand their mandate to become leaders.[19]

Based on the Hadith on the prohibition of women becoming leaders, Imam al-Syawkani (W. $1250 \mathrm{H} / 1834 \mathrm{AD}$ ) said that the ban was because the woman was not an expert in government 
issues. There is no way someone who is not an expert in government can lead the way of a country. If a government is forced to give to women, then it is likely that the government will not advance, even destroy.[20, hal. 592]

According to Musthafa al-Siba'i (D. 1964 AD), the main cause of the state will be destroyed when led by women because the more dominant element of feeling is in women rather than the element of the mind. A leader should not put forward his feelings of being able to lead a country, precisely what is needed is a brilliant mind. The affairs of the state will not be resolved by feeling, but can only be resolved through the mind. The lack of women in the field of mind is what causes her to be hindered to become a leader.[21, hal. 523]

Apparently, various views that arise from the scholars reject the leadership of women reading the textual side only, but do not see the context when the Hadith appeared (asbabul wurud). Nevertheless, this kind of view is valid, especially in terms of the quality of hadith is narrated by famous narrators in hadith science, such as Bukhari (W. 256 H), an-Nasa'i (W. 303 H), Turmudzi (W. 279 H) and Ahmad (W. 855 AD). But it is also important to look at the contextuality side of the Hadith. Because, the scholars who agree on the leadership of women study is done contextually.

When viewed in terms of context, the Hadiths are based on the events of the king kisra in Persia. The Messenger of Allaah (peace and blessings of Allaah be upon him) sent 'Abdullah ibn Hudzafah as-Sami to send a letter to the ruler of Bahrain to be delivered to Kisra in Persia. After receiving a letter from 'Abdullah ibn Hudzafah the authority gave the letter to Kisra. But after reading the letter from the Prophet (peace and blessings of Allaah be upon him), he refused his invitation and tore up his letter. This event was then heard by the Prophet (s), then he said: "Anyone who rips letters from me, torn (himself and the kingdom) that person".[22, hal. 159]

And what followed was true for the Persians. The Persian Empire was in a state of disquisition, rebellion and power struggles ensued within it. The pioneer of the rebellion was none other than King Kisra's own son, Syairawaihi. Syairawaihi managed to seize power and kill his father (King Kisrah). However, before he was killed King Kisrah had put poison in a special closet, because he knew the closet would one day be opened by his son. Shortly after King Kisrah's death, Syairawaihi opened the special closet and exposed himself to the poison that had been prepared by his father. In the end, Syairawaihi was killed by the poison. The leadership vacancy in Persia at the time made syairawaihi's daughter Buwaran her position as leader. When the Prophet (peace and blessings of Allaah be upon him) heard the news of the king of Persia, he said, "O my people! "No woman shall prosper."[22][12]

The words of the Messenger of Allaah (peace and blessings of Allaah be upon him) were true. Because, when leading Persia, Buwaran was not a just, wise and visionary leader. During his time in charge, he often acted unfairly and greedily, the interests of the government built not for the benefit of the people, but for his own interests.[13][23, hal. 7-9]

According to Persian tradition, before the events of the war, the heads of state were always led by men. But what happened during the next government was led by women, namely the leadership of Buwaran binti Syairawaihi. That leadership is certainly in contrast to the traditions that have existed. In fact, in those days the existence of women was still considered one-sided and had the incompetence to be a leader. On the other hand, women in those days were certainly not like in the present, their knowledge, insight and movement were very limited and covered by male domination. So it is natural that the leadership of Buwaran binti Syairawaihi caused Persia to be destroyed.

In this kind of socio-historical condition, the Prophet (s) stated that a nation that hands over leadership affairs to women will not succeed. Thus, the Hadith relating to female leadership had a clear context, namely the events of the destruction of the Persian empire. This kind of context, 
of course, is different from the current situation. Because, not a few women in this day and age, have good insight and knowledge about leadership. On the other hand, the position of women today, in contrast to the past conditions, today the existence of women is so appreciated and respected. Thus, hadith related to the above is not absolute, but more contextual/specific to a matter. If there are women who have insight and knowledge and are skilled in leadership science, then the path to becoming a leader is very wide open.

The view that allowed women to become leaders was approved by at-Thabari (D. 310 $\mathrm{H} / 923 \mathrm{CE}$ ). According to her, the ability of women to be leaders is based on the ability of women to be witnesses to the marriage. In this context there is equality in the question of witnesses between men and women. Therefore, this equality also applies to the issue of leadership. On the other hand, hadith related to the inability of women to be leaders should be seen and understood from the context that is the news is not part of the provisions of the law.[22]

The same opinion from at-Thabari (W. 310 H/923 AD) was also conveyed by Mahmud Syaltut (D. 1963 AD). He explained that the human behavior between men and women has something in common. God is all-merciful. bestow upon women as they are bestowed upon men. He conferred upon them both the potential and the ability to assume responsibility. All these responsibilities will surely be counted by Him.[24][25, hal. 8]

The same responsibility indicates that men and women are equal in the eyes of Allah. This similarity shows that if the two have similar potentials, then if men are able to become leaders on the basis of the same potential, women can also become leaders. Thus the Hadith that does not allow women to become leaders must be seen from the side of the hadith exit, not merely understand it textually.[11]

According to Ali Yafie (L. 1926 AD), Hadith that does not allow women to be leaders does not prohibit all women from becoming leaders of society or only applies to women who are not able. However, nowadays many women are actually able to lead society. The events that occurred in the Persian empire were special events, not general. The hadith also specializes in one event. Therefore in different events / contexts, when many emerging women have the ability to be leaders, then such a thing is not something forbidden.[26]

One of the figures who was quite harsh in responding to hadith banning women from becoming leaders was Fatima Mernissi (W. 2015 AD). In Mernissi's view, every Hadith derived from the Prophet could not be discriminatory, because he believed the Apostle was a person who was always able to be fair to his people, both men and women. Thus, if there is a Hadith that seems to corner women, it becomes worthy to be reviewed and not taken for granted.

According to Mernissi (W. 2015 AD), hadith related to the prohibition of women to become leaders needs to be seen in terms of context, so that it can study the historical side, where historically the Hadith is closely related to the case of the power struggle in Persia between the king kisra and his son who killed both so that the leadership continued by the granddaughter of the king kisra who actually did not have expertise/authority in leading. If the Hadith is used as proof of the inability of women to be leaders, it is certainly very contrary to the fact of the Koran that tells about women who successfully led a large country, namely the queen named Balqis the leader of saba.[24][22]

Not until there, according to Mernissi sanad side in hadith it also looks problematic. Because the sanadnya line comes from Abu Bakrah. There are at least a few records that are the path of Abu Bakrah's sanad in question by Mernissi; first, Abu Bakrah was sentenced by [27, hal. 141] Caliph 'Umar ibn Khattab for not being able to prove the accusation of adultery to alMughirah ibn Shu'bah. In one of the criteria of acceptance of Hadith, according to Imam Malik is the bearer of hadith it is not a liar. Thus, the Hadith carried by Abu Bakrah is unacceptable, because it has committed a false act.[24] 
Secondly, historically, Abu Bakrah remembers the Hadith, when 'Aisha suffered defeat in Jamal's war with 'Ali ibn Abi Talib. But the initial attitude taken by Abu Bakrah was neutral, not siding with both. However, when 'Aisha suffered defeat she revealed the Hadith. It was as if he was about to corner 'Aisha. Based on these two things Mernissi asserted, the existence of Abu Bakrah in the path of sanad, making the Hadith can still be debated, even though this Hadith is narrated by the imam Bukhari.[22]

Similar things were expressed by Nasaruddin Umar (L. 1959 AD). According to him, Hadith derived from Abu Bakrah is categorized as Saheeh Hadith, but has its own historical background, so it can not be immediately used as a general evidence. In fact, this hadith was popularized by Abu Bakrah who was a former slave, when he was faced with difficult conditions, where he had to support 'Ali ibn Abi Talib as the fourth caliph at that time or support 'Aisha who was the wife of the Prophet (s). In this condition Abu Bakrah then popularized the Hadith about the success of women when becoming leaders; "there shall be no luck a people who give up their affairs to a woman". On the other hand, save Nasaruddin Umar, This hadith is a response to the spontaneity of the Prophet (s) after hearing the chaos that occurred between the king kisra and his son, until then his power fell into the hands of his granddaughter who was indeed at that time immature to lead a government. And as is known, in the past Persia was one of the largest power centers in the world that competed fiercely with the great Roman empire. Thus, it can be said that the Apostle's statement delivered by Abu Bakrah appeared in a capacity as a political observer.[21][28]

The opinions of groups that disagree on the prohibition of women becoming leaders, it seems that the Hadith has its own context. Thus, understanding it should also be done contextually. Clearly, the context of the Hadith is the description of the Persian condition led by a woman who does not have the ability to lead. This condition certainly can not be the same as women today, where at this time not a few women are worthy to be leaders because of their knowledge and cleverness. In other words, if the criteria for leadership are in women, it becomes appropriate for her to compete with anyone (male and female) to be a leader.

A contextual approach to studying a Hadith, in such cases, seems indispensable. With it can be clearly drawn background (asbabul wurud) from Hadith that talks about the inability of women to be leaders. So that the assessment of the Hadith becomes more objective. This kind of approach is done by those who give views on the possibility of women becoming leaders.

The debate or difference of opinion between the scholars regarding whether or not women can be leaders, is actually a reasonable matter. Each of the scholars has their own reasons for understanding the Hadith. For those who use a textual approach to female leadership is not permissible, but for those who use contextual/socio-historical approaches this kind of thing is permissible. Therefore, whether or not women become leaders depends on the approach taken in studying hadith related to female leadership.

\section{Conclusion}

Differences of opinion between scholars regarding the leadership of women / related to hadith derived from the path of Abu Bakrah, seyogyanya due to differences in the approach used in understanding the Hadith. Scholars say that women should not be leaders because the approach used in reading the Hadith is a textual approach. Among the scholars representing him are Imam Shafi'i, Imam Malik, Ahmad ibn Hanbal, al-Baghawi, al-Syawkani and Musthafa alSiba'i. 
Meanwhile, scholars who approve of women's leadership, because of the reading/study of the Hadith contextually or using a socio-historical approach. Thus, in their reading, the Hadith is specific in accordance with the correlation of its occurrence, and can not / apply in general (to all women). Scholars representing this opinion include al-Thabari, Mahmud Syaltut, Fatima Mernissi, Ali Yafie and Nasaruddin Umar.

\section{References}

[1] Hilary Kalmbach, "Social and Religious Change in Damascus: One Case of Female Islamic Religious Authority Social and Religious Change in Damascus : One Case of Female Islamic Religious Authority *," Br. J. Middle East. Stud., vol. 35, no. 1, hal. 37-41, 2008, doi: 10.1080/13530190801890238.

[2] L. Baselga-pascual dan V. Emilia, "Female leadership and bank performance in Latin America," Emerg. Mark. Rev., no. xxxx, hal. 100807, 2021, doi: 10.1016/j.ememar.2021.100807.

[3] F. Battaglia et al., "Does gender influence leadership roles in academic surgery in the United States of America? A cross-sectional study," Int. J. Surg., vol. 83, no. June, hal. 67-74, 2020, doi: 10.1016/j.ijsu.2020.08.029.

[4] Mahmud Syaltut, And when We made the sun and the sun a prophet. Cairo: Al-Idârah al-Âmah li al-Azhar, 1959.

[5] J. Chyu et al., "Women in Leadership in Urology : The Case for Increasing Diversity and," Urology, 2020, doi: 10.1016/j.urology.2020.07.079.

[6] A. T. Bui, C. V. Nguyen, T. P. Pham, dan D. T. Phung, "International Review of Financial Analysis Female leadership and borrowing constraints : Evidence from an emerging," Int. Rev. Financ. Anal., no. 502, hal. 1-14, 2019, doi: 10.1016/j.irfa.2019.01.012.

[7] C. Capella, L. Schlegel, P. Shenot, dan A. Murphy, "Female Representation at High-profile Urology Conferences, 2014-2019: A Leadership Metric," Urology, hal. 1-5, 2020, doi: 10.1016/j.urology.2020.05.049.

[8] Baidi, P. Heldy Ramadhan Putra, dan Junaidah, "The effect of leadership style and work motivation on work productivity for teachers in all state junior high schools of surakarta," Univers. J. Educ. Res., vol. 8, no. 3D, hal. 67-72, 2020, doi: 10.13189/ujer.2020.081710.

[9] B. Lewis, The Arab in History. London: Arrow Books, 1958.

[10] A. H. Eagly dan L. L. Carli, "The female leadership advantage : An evaluation of the evidence," vol. 14, hal. 807-834, 2003, doi: 10.1016/j.leaqua.2003.09.004.

[11] A. Wadud, Qur'an and Women: Rereading the Sacred Text From a Woman's Perspective. New York: Oxford University Press, 1999.

[12] M. Galante dan R. M. Ward, "Female student leaders : An examination of transformational leadership , athletics , and self-esteem," PAID, vol. 106, hal. 157-162, 2017, doi: 10.1016/j.paid.2016.11.017.

[13] L. Girdauskiene dan F. Eyvazzade, "The profile of an effective female leadership in multicultural context," Procedia - Soc. Behav. Sci., vol. 210, hal. 11-20, 2015, doi: 10.1016/j.sbspro.2015.11.323.

[14] M. Arnez, "EMPOWERING WOMEN THROUGH ISLAM: FATAYAT NU BETWEEN TRADITION AND CHANGE," vol. 1, hal. 59-88, 2010, doi: 10.1093/jis/etp025.

[15] J. E. Smith, C. A. Ortiz, M. T. Buhbe, dan M. Van Vugt, "Obstacles and opportunities for female leadership in mammalian societies : A comparative perspective," Leadersh. Q., no. September, hal. 115, 2018, doi: 10.1016/j.leaqua.2018.09.005.

[16] G. Tate dan L. Yang, "Female leadership and gender equity: Evidence from," J. financ. econ., hal. 1-21, 2014, doi: 10.1016/j.jfineco.2014.01.004

[17] M. A. Harjoto, I. Laksmana, dan W. E. Lee, "Advances in Accounting Female leadership in corporate social responsibility reporting: Effects on writing, readability and future social performance," Adv. Account., hal. 100475, 2020, doi: 10.1016/j.adiac.2020.100475.

[18] Abi Muhammad ibn Mas'ud al-Baghawi, Syarhus-Sunnah. Beirut: Darul Kitab ‘Amaliyah. 
[19] C. Rapanta dan D. Badran, "Supporting Emirati females leadership skills through teaching them how to debate: Design , assessment, and considerations," Int. J. Manag. Educ., vol. 14, no. 2, hal. 133-145, 2016, doi: 10.1016/j.ijme.2016.03.004.

[20] Muhammad ibn Ali ibn Muhammad Syawkani, Nail al-Authar. Beirut: Dar al-Fikr, 1900.

[21] al-Zamakhsyari, Tafsîr al-Kasysyâf, Juz I. Egypt: Isa al-Bab al-Halab wa Syirkah.

[22] Ibn Hajar al-'AsqaLani, Fath al-Bāri: Sharh Saheeh al-Bukhari, Juz 8. Lebanon: Dar al-Kutub al-Ilmiyah, 2003.

[23] S. Kumar, A. Economics, N. Prakash, dan A. Economics, "Effect of political decentralization and female leadership on institutional births and child mortality in rural Bihar, India," Soc. Sci. Med., 2017, doi: 10.1016/j.socscimed.2017.04.013.

[24] Said Aqil Husin al-Munawwar, Asbâbul Wurûd: Critical Study of the Prophet's Hadith through Socio-Historical and Contextual Approaches. Yogyakarta: Student Library, 2001.

[25] P. Roberto, G. Walczak, dan I. Todescat, "The queen bee : A myth? The e ff ect of top-level female leadership on subordinate females," Leadersh. Q., no. March, 2018, doi: 10.1016/j.leaqua.2018.03.002.

[26] S. Brenner, "Private Moralities in the Public Sphere: Democratization, Islam, and Gender in Indonesia," vol. 113, no. 3, hal. 478-490, 2011, doi: 10.1111/j.1548-1433.2010.01355.x.

[27] Wahbah Zuhaili, al-Tafsir al-Munir fi al-Aqi ah wa al-Shari'ah wa al-Manhaj, Juz I. Beirut: Dar al-Fikr al-Ma'asir, 1991.

[28] Shobron; Amrin; dan I. M. Rosyadi, "Islamic Education Values in the Tradition of Peta Kapanca of Mbojo Community Tribe in West Nusa Tenggara Department of Islamic Law Universitas Muhammadiyah Surakarta Indonesia Mut122@ums.ac.id,” Int. J. Adv. Sci. Technol., vol. 29, no. 5, hal. 6802-6812, 2020. 